\title{
HUKUM SALAT BERJEMAAH DI MASJID DENGAN SAF TERPISAH KARENA WABAH COVID-19
}

\author{
Eko Misbahuddin Hasibuan
}

King Saud University, Saudi Arabia

Email: m81hasib@gmail.com

\section{Muhammad Yusram}

Sekolah Tinggi Ilmu Islam dan Bahasa Arab (STIBA) Makassar

Email: yusrananshar@stiba.ac.id

Keywords:

Prayer, Congregation, Line, Pandemic, Coronavirus

\begin{abstract}
This article aimed to describe the law of congregational prayer in mosque with tenuous line due to Corona outbreak that hits this country. This study used a descriptive qualitative approach that describes Islamic concepts that need to be understood and implemented in the matter of congregational prayer in unusual situation by analyzing the propositions and opinions of the scholars. The results of this study indicate that if there were instruction to temporarily discontinue Friday prayers and congregational prayers in the mosque that is merely an appeal and an institution or mosque takmir decided to continue conducting congregational prayers in the mosque by applying social distancing, then their congregational prayers would be considered legal. However, obeying the appeal of the authorities, both the government and Indonesian Council of Ulama (MUI), is more recommended and preferred. It is because an appeal, although not compulsory, is intended to benefit the community in general, and the appeal is issued owing to the danger of Corona outbreak that is obvious and real. This appeal is enough to be considered excuse for discontinuing the congregational prayers in the mosque and substituting Friday prayer with fourrakat Zuhr prayer.
\end{abstract}

Kata kunci:

Salat, Berjemaah, Saf, Wabah, Corona

\begin{abstract}
Artikel ini bertujuan untuk mendeskripsikan hukum salat berjemaah di masjid dengan keadaan saf yang terpisah (berjarak/tidak rapat) disebabkan karena adanya wabah Corona yang melanda negeri ini. Penelitian ini menggunakan metode pendekatan kualitatif deskriptif yang memaparkan bagaimana konsep Islam yang perlu dipahami dan diterapkan dalam permasalahan salat berjemaah dengan kondisi yang tidak normal, dengan menganalisis dalil-dalil dan pendapat para ulama. Hasil penelitian ini menunjukkan bahwasanya jika terdapat arahan untuk menghentikan sementara salat Jumat dan salat berjemaah di masjid yang sifatnya sekadar imbauan, kemudian sebuah lembaga atau badan takmir masjid memilih tetap melaksanakan salat berjemaah di masjid dengan menerapkan cara social distancing, maka salat jemaah mereka dianggap sah. Namun, menaati imbauan pihak berwenang baik pemerintah atau MUI lebih dianjurkan dan diutamakan. Karena imbauan tersebut, meski belum diwajibkan, bertujuan untuk kemaslahatan
\end{abstract}




\section{PENDAHULUAN}

Pada saat ini, Allah 'Azza wa Jalla sedang menguji umat manusia dengan wabah virus covid-19 yang telah menjadi pandemik. Wabah yang menyebar dengan cepat dan dalam lingkup yang sangat luas, dengan sendirinya berubah menjadi 'umum al-balwa, yakni musibah atau kesulitan yang menimpa manusia secara global, termasuk di dalamnya kaum muslimin di beberapa negara. Virus Corona atau Covid-19 yang sedang melanda dunia di akhir tahun 2019 hingga saat ini disinyalir berasal dari Wuhan, China. Korban pun berjatuhan dan diprediksi menyebar ke seluruh penjuru dunia. Jika keadaan ini tidak ditangani dengan baik dan cepat, maka akan memberikan dampak negatif yang luar biasa di seluruh belahan bumi ini. Pemerintah China di wilayah Wuhan sebagai wilayah awal penyebaran virus ini telah melakukan isolasi.

Di China sendiri, dalam tempo singkat perpindahan virus dari orang ke orang sudah lintas provinsi, yang berlanjut lintas negara dan kini lintas benua. Hingga akhirnya World Health Organization (WHO) secara resmi pada tanggal 12 Maret 2020 telah menyatakan bahwa virus Covid-19 sebagai pandemik. Virus Corona di Wuhan merupakan virus jenis baru yang menular. Coronavirus adalah kumpulan virus yang bisa menginfeksi sistem pernapasan dan menyebabkan kematian. Secara historis virus Corona pertama kali diidentifikasi sebagai penyebab flu biasa pada tahun 1960. ${ }^{1}$ Sedangkan menurut World Health Organization (WHO), Virus Corona adalah virus yang menyebabkan flu biasa hingga penyakit yang lebih parah seperti sindrom pernapasan timur tengah (MERS-CoV) dan sindrom penafasan akut parah (SARSCoV). Bahkan terdapat dugaan bahwa virus Corona awalnya ditularkan dari hewan ke manusia. Namun, kemudian berdasarkan penelitian yang mutakhir diketahui bahwa virus Corona juga menular dari manusia ke manusia. Hingga saat ini, belum ada vaksin untuk mencegah infeksi virus Corona jenis baru yang muncul di Wuhan yang secara resmi disebut Covid-19. ${ }^{2}$

${ }^{1}$ Lihat, Aisha M. al-Osail and Marwan J. Al-Wazzah, The History and Epidemiology of Middle East Respiratory Syndrome Corona Virus, Multidisciplinary Respiratory Medicine (2017) 12:20. DOI 10.1186/s40248-017-0101-8.

${ }^{2}$ Lihat, Jimmy Whitworth, COVID-19: A Fast Evolving Pandemic, Trans R Soc Trop Med Hyg 2020; 00: 1-2. doi:10.1093/trstmh/traa025. 
Wabah Covid-19 dinyatakan sebagai darurat kesehatan masyarakat dan menjadi perhatian dunia oleh World Health Organization (WHO). Untuk mengantisipasi itu semua otoritas berwenang China telah melakukan langkahlangkah ketat, termasuk menghentikan penerbangan dan transportasi umum di Wuhan dan kota-kota besar lainnya, menut up pasar-pasar hewan, memperpanjang periode liburan tahun baru sebagai upaya mencegah perjalanan massal, mengurangi pergerakan di dalam kota, meminimalisir pertemuan massal, menutup sekolah, pembatasan jam kerja di kantor dan pabrik serta membatasi pergerakan di jalanan dan memberlakukan lockdown di Wuhan dan seluruh Provinsi Hubei serta negara-negara lain telah menerapkan pembatasan penerbangan ke China. ${ }^{3}$

World Health Organization (WHO) telah menjelaskan beberapa cara untuk menghindari virus corona, di antaranya dengan menerapkan social distancing atau jaga jarak minimal 1 meter dari orang yang terindikasi terpapar virus Corona. Secara umum, tak seorang pun dapat mengetahui secara pasti seseorang itu positif terjangkit virus Corona atau tidak. Olehnya itu sistem jaga jarak dan tidak kontak langsung ini kemudian diterapkan di manapun, terhadap siapapun, khususnya di tempat umum. Dengan demikian, upaya social distancing dan segala ikhtiar menjaga diri dari penyebaran virus Corona tersebut juga terlihat berdampak langsung pada amal ibadah, seperti ibadah haji dan umrah, salat jemaah, salat Jumat, salat jenazah, dan lain sebagainya.

Berdasarkan pada latar belakang di atas, maka hal yang perlu untuk dikaji dan dijawab dalam penelitian ini adalah bagaimana hukum salat berjemaah di masjid dengan saf yang terpisah (berjarak/tidak rapat) karena adanya wabah covid-19? Sehingga tujuan dari penelitian ini adalah untuk mengetahui hukum salat berjemaah di masjid dengan keadaan saf yang terpisah (berjarak/tidak rapat) disebabkan oleh adanya wabah covid-19 yang melanda negeri ini.

Penelitian ini menggunakan metode pendekatan kualitatif deskriptif sebagai upaya dalam memahami berbagai konsep yang ditemukan dalam proses penelitian, dengan menerapkan teknik content analysis (analisis isi) dan riset kepustakaan (library research). Teknik content analysis merupakan metode penelitian yang digunakan untuk mengetahui simpulan dari sebuah teks/manuskrip. Atau dengan kata lain, analisis isi merupakan metode penelitian

${ }^{3}$ Lihat, Hien Lau, et.all, The Positive Impact of Lockdown in Wuhan on Containing the COVID-

19 Outbreak in China, Journal of Travel Medicine, taaa037, https://doi.org/10.1093/jtm/taaa037. 
yang ingin mengungkap gagasan penulis yang termanifestasi maupun yang laten. Sedangkan riset kepustakaan (library research) pada penelitian ini menggunakan jenis dan sumber data sekunder yang diperoleh dari hasil penelitian, artikel dan buku-buku referensi yang membahas topik yang berkaitan dengan fokus dan masalah penelitian. ${ }^{4}$

Terdapat beberapa penelitian terdahulu yang juga membahas seputar virus Corona (Covid-19) ini dari berbagai macam aspek. Ada yang mengkaji berkaitan dengan aspek kebijakan pemerintah, ada juga yang membahas dari sisi konsep Islam dalam menghadapi covid-19 ini, serta pembahasan seputar penggunaan masker saat melakukan salat berjemaah. Secara rinci penelitian terdahulu yang dimaksudkan adalah sebagai berikut:

Dari dimensi agama, Indriya (2020) melakukan penelitian yang bertujuan untuk mengetahui bagaimana konsep tafakkur dalam al-Qur'an dalam menyikapi Corona virus (Covid-19). Berdasarkan hasil penelitian tersebut ditemukan bahwa tafakur Covid-19 dalam perspektif agama Islam menghasilkan beberapa jalan yaitu melalui: pertama, karantina atau mengisolasi daerah yang terkena wabah adalah sebuah tindakan yang tepat; kedua, bersabar; ketiga, berbaik sangka dan berikhtiar; keempat, memperbanyak doa dan tawakkal kepada Allah Ta'ala. ${ }^{5}$ Dari dimensi psikologi sosial, Dana Riksa Buana (2020) melakukan penelitian yang bertujuan untuk menganalisis perilaku masyarakat Indonesia dalam menghadapi pandemik virus Corona (Covid-19) dan bagaimana kiat menjaga kesejahteraan jiwa. Berdasarkan hasil penelitian tersebut menunjukkan bahwa masih banyaknya masyarakat Indonesia yang tidak mematuhi imbauan dari pemerintah untuk menanggulangi pandemik virus corona ini, diakibatkan oleh salah satu konsep di dalam psikologi yang dinamakan bias kognitif ${ }^{6}$. Selain itu,

${ }^{4}$ Azwar Iskandar dan Khaerul Aqbar, Kedudukan Ilmu Ekonomi Islam di Antara Ilmu Ekonomi dan Fikih Muamalah: Analisis Problematika Epistemologis, Nukhbatul 'Ulum: Jurnal Bidang Kajian Islam, Vol. 5, No. 2 (2019), h. 88-105. https://journal.stiba.ac.id/index.php/nukhbah/article/view/77.

${ }^{5}$ Indriya, Konsep Tafakkur dalam Alquran dalam Menyikapi Coronavirus Covid-19, Salam: Jurnal Sosial dan Budaya Syar'i, Vol. 7, No. 3 (2020), h. 211-216.

${ }^{6}$ Bias kognitif adalah kesalahan sistematis dalam berpikir yang memengaruhi keputusan dan penilaian yang dibuat seseorang. Jenis bias kognitif yang tepat untuk menjelaskan fenomena ini adalah bias optimisme, bias emosional, dan efek Dunning-Kruger. Untuk dapat mengatasi bias kognitif ini langkah-langkah yang dapat dilakukan oleh masyarakat Indonesia adalah tidak membuat keputusan dalam waktu yang mendesak, hindari membuat keputusan ketika seseorang secara kognitif sedang melakukan pekerjaan lebih dari satu, tidak membuat keputusan pada malam hari jika seseorang adalah orang yang beraktivitas atau bekerja yang di mulai pada pagi hari (begitupun sebaliknya), hati-hati dalam mengambil keputusan saat sedang berbahagia, dan berpikir berdasarkan data dan fakta.

Eko Misbahuddin H., Muhammad Yusram. Hukum Salat Berjemaah... 
untuk tetap menjaga kesehatan mental maka aspek-aspek yang dapat dilakukan berkenaan dengannya yakni: pertama, orang yang bahagia adalah orang yang mengerti makna dalam hidupnya: kedua, orang yang menjaga dirinya dalam emosi yang positif; dan ketiga adalah orang yang terus mengasah diri spiritualnya. $^{7}$

Dari sisi kebijakan pemerintah, Nur Rohim Yunus dan Annissa Rezki (2020) melakukan penelitian yang bertujuan untuk mengetahui bagaimana kebijakan pemberlakuan lockdown sebagai antisipasi penyebaran virus covid-19. Berdasarkan hasil penelitian tersebut ditemukan bahwa Indonesia sudah mengalami kondisi yang mana kekhawatiran masyarakat terhadap virus covid-19 cukup besar, sehingga diperlukan kebijakan pemerintah untuk melakukan lockdown, sebagai upaya memutus mata rantai penyebaran virus covid-19. ${ }^{8}$ Senada dengannya, Zahrotunnimah (2020) melakukan penelitian yang bertujuan untuk mengetahui bagaimana langkah taktis pemerintah daerah dalam pencegahan penyebaran virus covid-19 di Indonesia. Berdasarkan hasil penelitian tersebut menunjukkan bahwa pemerintah daerah telah banyak melakukan stategi komunikasi kepada masyarakat wilayahnya masing-masing melalui teknik koersif, informatif, canalizing, edukatif, persuasif dan redudancy dalam mengemas pesan berupa instruksi, imbauan kepada masyarakat untuk mencegah penularan virus covid-19 di wilayahnya masing-masing. Akan tetapi masih belum melakukan teknik koersif sampai pada tahap memberikan sanksi untuk efek jera bagi pelanggarnya. Pemerintah pusat juga belum memaksimalkan perannya dalam menggunakan strategi komunikasi secara komprehensif bagi seluruh pemerintah daerah. Hal ini karena tidak adanya komando nasional dari pemerintah pusat yang dikenal lambat dalam mencegah penularan virus covid-19 yang sudah menjadi bencana global (pandemik). ${ }^{9}$

Segayut dengan penelitian di atas, Mukharom dan Havis Aravik (2020) melakukan penelitian yang bertujuan untuk mengetahui bagaimana kebijakan Nabi Muhammad shallallahu 'alaihi wasallam dalam menangani wabah penyakit menular dan bagaimana implementasi kebijakan tersebut dalam konteks

${ }^{7}$ Dana Riksa Buana, Analisis Perilaku Masyarakat Indonesia dalam Menghadapi Pandemi Virus Corona (Covid-19) dan Kiat Menjaga Kesejahteraan Jiwa, Salam: Jurnal Sosial dan Budaya Syar'i, Vol. 7, No. 3 (2020), h. 217-226.

${ }^{8}$ Nur Rohim Yunus dan Annissa Rezki, Kebijakan Pemberlakuan Lockdown sebagai Antisipasi Penyebaran Corona Virus Covid-19, Salam: Jurnal Sosial dan Budaya Syar'i, Vol. 7, No. 3 (2020), h. 227-238.

${ }^{9}$ Zahrotunnimah, Langkah Taktis Pemerintah Daerah dalam Pencegahan Penyebaran Virus Corona Covid-19 di Indonesia, Salam: Jurnal Sosial dan Budaya Syar'i, Vol. 7, No. 3 (2020), h. 247-260. 
menanggulangi virus covid-19. Berdasarkan hasil penelitian tersebut memperlihatkan bahwa wabah virus covid-19 tidak jauh beda dengan kondisi di masa Rasulullah Muhammad shallallahu 'alaihi wasallam, dengan adanya wabah pada saat itu. Kebijakannya adalah melakukan karantina wilayah baik ke dalam maupun ke luar wilayah, sehingga tidak menyebar. Dalam konteks saat ini, terkait kasus virus covid-19, lockdown dan social distancing menjadi solusinya, termasuk segera menemukan anti virusnya, sehingga dapat mengobati dan menghentikan penyebarannya. ${ }^{10}$

Penelitian mutakhir dilakukan oleh Syandri dan Fadlan Akbar (2020) yang bertujuan untuk mengetahui bagaimana hukum dalam Islam ihwal penggunaan masker penutup wajah saat salat sebagai langkah pencegahan wabah virus covid-19. Berdasarkan hasil penelitian tersebut ditemukan bahwa hukum asal menggunakan penutup mulut (masker) ketika salat adalah "makruh tanzih" yaitu makruh yang tidak membatalkan salat. Akan tetapi, pada kondisi tertentu seperti adanya hajat, maka penggunaan masker dalam salat hukumnya boleh. Bahkan bisa meningkat derajatnta kepada hukum dianjurkan jika seseorang yang akan menghadiri salat jemaah dalam kondisi kurang sehat seperti demam, batuk atau flu. Hal ini diharapkan dapat mencegah tersebarnya virus covid-19 dalam masyarakat. ${ }^{11}$

Adapun dalam penelitian ini, yang akan dikaji secara mendalam adalah tentang bagaimana tinjauan dalam hukum Islam terhadap seseorang yang melakukan salat berjemaah dalam satu masjid dengan keadaan saf yang berjauhan atau tidak rapat dalam barisannya dengan tujuan untuk menghindari penularan virus covid-19 antara satu dan yang lainnya. Hal ini dimaksudkan untuk mendapatkan jawaban yang tegas dan ilmiah di atas dalil yang jelas atas keraguan bagi masyarakat yang ingin melaksanakan salat berjemaah di masjid dengan keadaan demikian. Sementara disaat yang bersamaan telah ada surat edaran resmi atau imbauan dari pemerintah ${ }^{12}$ selaku pemangku kebijakan dan

${ }^{10}$ Mukharom dan Havis Aravik, Kebijakan Nabi Muhammad Saw. Menangani Wabah Penyakit Menular dan Implementasinya dalam Konteks Menanggulangi Coronavirus Covid-19, Salam: Jurnal Sosial dan Budaya Syar'i, Vol. 7, No. 3 (2020), h. 239-246.

${ }^{11}$ Syandri dan Fadlan Akbar, Penggunaan Masker Penutup Wajah Saat Salat sebagai Langkah Pencegahan Wabah Coronavirus Covid-19, Salam: Jurnal Sosial dan Budaya Syar'i, Vol. 7, No. 3 (2020), h. 261-268.

${ }^{12}$ Dokumen Resmi dan Protokol Penanganan Covid-19 oleh Kementerian Kesehatan RI. https://www.kemkes.go.id/article/view/20031700001/Dokumen-Resmi-dan-Protokol-

Penanganan-COVID-19.html Diakses pada tanggal 7 April 2020.

Eko Misbahuddin H., Muhammad Yusram. Hukum Salat Berjemaah... 
Majelis Ulama Indonesia (MUI) ${ }^{13}$ tentang pengadaan salat berjemaah di masjid yang ditiadakan untuk sementara waktu. Edaran terkini juga dikeluarkan oleh Menteri Agama yang meberikan arahan tentang kondisi beribadah kaum muslimin selama wabah covid-19 masih melanda Indonesia. ${ }^{14}$

\section{PEMBAHASAN}

\section{Perkembangan Virus Covid-19 di Indonesia dan Imbauan Social Distancing}

Belakangan ini, pemerintah Indonesia terus melakukan berbagai macam upaya dan pembenahan dalam rangka pencegahan penularan dan meminimalisir orang yang terinfeksi virus covid-19 ini. Sebelumnya, pemerintah Indonesia terkesan untuk tidak begitu aktif dalam pemberian informasi kepada publik terkait virus covid-19 yang telah masuk dan mewabah di Indonesia ini. Hal tersebut dilakukan dimaksudkan untuk menghindari kepanikan masyarakat dan juga sebagai usaha dalam menghindari isu-isu yang berkembang yang tidak jelas kebenarannya.

Pada hari Kamis, 19 Maret 2020 dari pemberitaan media detiknews.com, disampaikan bahwa juru bicara pemerintah untuk penanganan virus covid-19, Achmad Yulianto mengatakan bahwa pemerintah tengah mengupayakan dilakukannya tes massal virus covid-19 dan perlu dilakukan adanya uji Polymerase Chain Reaction (PCR). ${ }^{15}$ Yulianto juga mengatakan secara resmi terkait informasi perkembangan kasus covid-19 bahwa sampai dengan hari Kamis, 19 Maret 2020 penelitian yang dilakukan oleh World Health Organization (WHO) yang menghimpun seluruh ahli virus corona di dunia masih nihil dan belum mendapatkan suatu kesepakatan yang bisa dijadikan standar dunia terkait dengan pengobatan yang definitif terhadap covid-19 ini.

Berkaitan dengan perkembangan virus covid-19 tersebut, maka pemerintah membuat kebijakan sebagai langkah pertama yaitu anjuran untuk melakukan social distancing. Hal ini dimaknai bahwa pemerintah menyadari sepenuhnya bahwa penularan dari virus covid-19 ini dapat bersifat percikan lendir kecil dari dinding saluran pernapasan seseorang yang sakit yang keluar pada saat batuk ataupun bersin. Oleh karena itu, pemerintah menganjurkan

${ }^{13}$ Fatwa Nomor 14 Tahun 2020 tentang Penyelenggaraan Ibadah dalam Situasi Terjadi Wabah Covid19. https://mui.or.id/berita/27674/fatwa-penyelenggaraan-ibadah-dalam-situasi-terjadi-wabahcovid-19/ Diakses pada tanggal 7 April 2020.

${ }^{14}$ Surat Edaran Menteri Agama Nomor SE.6 Tahun 2020 tentang Panduan Ibadah Ramadan dan Idul Fitri 1 Syawal 1441 H di Tengah Pandemik Wabah Covid-19.

${ }^{15}$ https://news.detik.com/berita/d-4945831/kemenkes-rapid-test-massal-corona-akandikonfirmasi-tes-per Diakses pada Sabtu 4 April 2020. 
kepada siapa saja yang mengalami batuk dan yang menderita penyakit influenza untuk menggunakan masker saat keluar rumah. Hal itu bertujuan untuk membatasi percikan droplet dari yang bersangkutan, dengan harapan dengan adanya pengaturan jarak antar orang tersebut, menutup kemungkinan peluang tertular penyakit dan terpapar virus covid-19 ini.

Implikasi dari anjuran tersebut adalah pertemuan-pertemuan yang melibatkan orang dengan jumlah yang besar dan yang memungkinkan terjadinya penumpukan orang maka harus dihindari. Oleh karena itu, sangat penting untuk disadari bersama dari seluruh komponen masyarakat untuk tidak melaksanakan kegiatan yang mengerahkan banyak orang dalam satu tempat yang tidak terlalu luas dan menyebabkan kerumunan. Hal ini dianggap sebagai salah satu upaya yang sangat efektif untuk mengurangi penyebaran virus. Dengan demikian, social distancing hendaknya diimplementasikan, baik dalam kehidupan sehari-hari, di lingkungan kerja ataupun di lingkungan rumah tangga. Selain itu, tetap melakukan pencegahan melalui upaya pola hidup bersih dan sehat dengan selalu mencuci tangan menggunakan sabun dengan air yang mengalir.

World Health Organization (WHO) secara resmi mengeluarkan pernyataan bahwa virus corona (covid-19) ini dianggap sebagai pandemik. ${ }^{16}$ Pernyataan itu dianggap tidak berlebihan sebab saat ini jumlah orang yang terkena terpapar virus covid-19 semakin meningkat dan jumlah kematian yang disebabkan oleh virus tersebut juga semakin banyak di seluruh dunia. Berdasarkan pada data resmi bahwa saat ini di dunia secara global penyebaran virus covid-19 ini telah melanda 207 negara dengan kasus yang terkonfirmasi sejumlah 1.056.159 jiwa dan angka kematian sebesar 57.206 jiwa. Adapun untuk kasus yang terjadi di Indonesia, data pemerintah pusat menunjukkan angka 2.273 orang yang positif terjangkit virus covid-19 dengan angka kematian sejumlah 198 jiwa. ${ }^{17}$

Sebagai bagian dari masyarakat dunia, Indonesia yang telah terjangkiti wabah covid-19 ini juga berkewajiban untuk melakukan upaya preventif atau cegah tangkal terhadap terjadinya penularan wabah virus yang meresahkan dunia (Public Health Emergency of International Concern), sebagaimana diamanatkan dalam regulasi internasional di bidang kesehatan. Oleh karena itu, dalam melaksanakan amanat ini, Indonesia harus menentukan sebuah kebijakan demi kemaslahatan seluruh masyarakat. Pemerintah pusat sebagai penentu kebijakan dalam menyikapi pandemik covid-19 ini telah mengeluarkan imbauan terkait tata

${ }^{16}$ Suatu penyakit yang tersebar luas di suatu kawasan, benua, atau di seluruh belahan dunia. ${ }^{17}$ https://www.covid19.go.id/ Diakses pada 5 April 2020. 
cara dalam berinteraksi sesama manusia dengan cara menerapkan social distancing. ${ }^{18,19}$ Kebijakan ini hendaknya diikuti dan dilaksanakan dimulai para pelaku (stakeholders) dalam rangka memecahkan suatu permasalahan tertentu. ${ }^{20}$ Hal positif yang diharapkan dari kebijakan pemerintah tersebut adalah berkurangnya jumlah masyarakat yang terpapar virus covid-19 dan pencegahan penularannya. Sebab dalam beraktivitas di luar rumah tidak terjadi kontak fisik secara langsung antara orang yang satu dengan yang lainnya sehingga dapat menjaga resiko penularan yang tinggi. Selain itu, upaya lain yang dilakukan pemerintah adalah menyiapkan hand sanitizer untuk masyarakat di beberapa area umum agar dapat digunakan setelah bersentuhan, dan selalu mengingatkan agar mencuci tangan untuk menghindari virus masuk ke dalam tubuh.

Namun demikian, realitas sebagian masyarakat Indonesia tidak mengindahkan imbauan pemerintah tersebut. Sebagian mereka merasa lebih mengerti kondisi pandemik virus ini. Mereka merasa dapat menjaga diri dengan baik walaupun berada di luar rumah atau di keramaian. Sehingga masih terlihat ramai di tempat-tempat ibadah, misalnya di masjid, orang-orang berkumpul untuk melaksanakan salat berjemaah sebagaimana biasanya dan kegiatan lainnya, walaupun telah ada imbauan dan edaran dari pemerintah maupun MUI tentang pelaksanaan ibadah tersebut. Fakta lapangan juga tampak masih banyak masyarakat Indonesia yang melakukan kegiatan keagamaan dengan jumlah ribuan orang. Mereka percaya dengan keyakinan penuh bahwa doa dapat menyelamatkan mereka, dan mereka beranggapan harusnya lebih takut kepada Allah Ta'ala dan bukan kepada virus covid-19.

Dalam beberapa keadaan di masjid-masjid tertentu, sebagian kaum muslimin masih juga melaksanakan salat berjemaah dengan memberikan jarak di antara mereka sehingga tampak saf yang tidak rapat, dengan alasan mencegah penularan virus covid-19 jika salah satu di antara mereka ada yang menderita hal tersebut.

\section{Hukum Salat Berjemaah di Masjid dengan Saf Terpisah}

\footnotetext{
${ }^{18}$ https://www.suara.com/news/2020/03/25/104701/pemerintah-tekankan-socialdistancing-harus-sampai-lingkup-keluarga Diakses pada tanggal 7 April 2020.

${ }^{19} \mathrm{https} / /$ news.detik.com/berita/d-4940726/tentang-social-distance-cara-pemerintah-cegahpenyebaran-virus-corona Diakses pada tanggal 7 April 2020.

${ }^{20}$ Akib Haerul dan Hamdan. (2016). Implementasi Kebijakan Program Makassar Tidak Rantasa di Kota Makassar, Jurnal Administrasi Publik, Volume 6, No. 2, 2016, h. 21-34.
}

Eko Misbahuddin H., Muhammad Yusram. Hukum Salat Berjemaah... 
Penelitian ini mencoba mengkaji dalam sudut pandang Islam tentang keadaan orang yang salat berjemaah dengan saf yang tidak rapat disebabkan oleh pemberlakuan jarak di antara mereka. Sebelum mengulas penjelasan hukum salat berjemaah di masjid dengan saf terpisah karena wabah virus covid-19 yang melanda, ada beberapa poin penting yang perlu dipahami bersama terlebih dahulu, yaitu:

Pertama, jika telah ada instruksi dari pihak yang berwenang, dalam hal ini pemerintah dan MUI, untuk menghentikan sementara kegiatan salat Jumat dan salat fardu berjemaah di masjid, maka wajib bagi seorang muslim untuk menaatinya.

Allah Subhanahu wa Ta'ala berfirman:

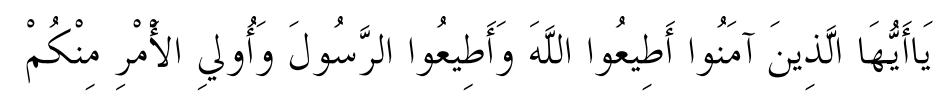

Terjemahnya:

"Hai orang-orang yang beriman, taatilah Allah dan taatilah Rasul-Nya, dan ulul amri di antara kamu." (Q.S. al-Nisa'/4: 59)

Ibnu Abbas, Mujahid, Atha' dan Hasan al-Bashri menafsirkan ulul amri sebagai ahli fikih dan agama. Abul 'Aliyah mengatakan yang dimaksud dengan ulul amri adalah ulama. Ibnu Katsir mengatakan, "Tampaknya -wallahu a'lamayat ini memaksudkan ulul amri adalah umara dan ulama."21

Kedua, jika larangan tersebut masih berupa imbauan, karena keadaan masih dianggap kondusif, dan imbauan tersebut bertujuan untuk pencegahan dini dari penyebaran virus covid-19, maka sebaiknya imbauan tersebut diikuti, karena mencegah lebih baik daripada mengobati. Hal itu tercermin dari kaidah sadd aldzarai $^{22,23}$ (tindakan preventif) dan al-dhararu yuza ${ }^{4}$ (menghilangkan mudarat). Keluarnya imbauan dari pemerintah atau MUI sudah dengan sendirinya menjadi uzur untuk meninggalkan salat Jumat dan salat berjemaah di masjid.

\footnotetext{
${ }^{21}$ Ismail bin Umar bin Katsir al-Dimasyqi, Tafsir al-Qur'an al-Azhim, Jilid II (Cet. II; Riyadh: Dar al-Thayyibah, 1420 H/ 1999 M), h. 345

${ }^{22}$ Muhammad bin Abdullah bin Bahadir al-Zarkasyi, Al-Bahru al-Muhith fi Ushul al-Fiqh, Wizarah al-Awqaf wa al-Syuun al-Islamiyah, Jilid VI (Cet. II; Kuwait: t.p., 1413 H/ 1992 M), h. 82.

${ }^{23}$ Muhammad bin Ali bin Muhammad al-Syaukani, Irsyadul Fuhul ila Tahqiq al-Haq min 'Ilmi al-Ushul, Jilid II (Cet. I; Damaskus: Dar al-Kitab al-Arabi, 1419 H/ 1999 M), h. 193.

${ }^{24}$ Tajuddin Abdul Wahhab bin Taqiyuddin al-Subki, Al-Asybah wa al-Nazhair, Jilid I (Cet. I; Beirut: Dar al-Kutub al-Ilmiyah, 1411 H/ 1991 M), h. 41.
} 
Ketiga, jika belum ada larangan atau imbauan khusus untuk daerah tertentu, karena penyebaran virus belum sampai ke daerah tersebut, dan masyarakat yakin bahwa daerahnya masih steril, maka salat Jumat dan jemaah di masjid tetap dilaksanakan seperti biasa, demi menjaga syiar Islam. Dalam kondisi ini, maka salat Jumat dan salat fardu berjemaah dilaksanakan sebagaimana mestinya.

Keempat, jika sebuah lembaga atau badan takmir masjid tetap memilih melaksanakan salat Jumat dan salat berjemaah di masjid setelah adanya imbauan dari pemerintah dan MUI, dengan menerapkan beberapa bentuk tindakan preventif, seperti memakai masker, social distancing (jaga jarak) saf salat, maka ada perbedaan pendapat antara ulama (kontemporer) tentang sah tidaknya salat dengan saf yang berjauhan, baik antara saf pertama dan kedua, maupun antara seorang dengan orang yang di kanan dan kirinya. Berikut pendapat para ulama tentang salat berjemaah dengan keadaan social distancing (jaga jarak 1 meter atau lebih antara jemaah):

Pendapat pertama; salat di masjid dengan model social distancing tidak dianggap salat berjemaah, maka salat ini dianggap salat sendiri. Di antara ulama yang berpendapat seperti ini adalah:

Syekh Abdul Muhsin al-Abbad. ${ }^{25}$ Ketika ditanya tentang hukum salat berjemaah dengan cara social distancing, beliau menjawab: "Salat (jemaahnya) tidak sah, hukumnya sama saja dengan saat mereka salat sendirian. "26 Tetapi beliau tidak menyebutkan dalil dari pendapat tersebut. Boleh jadi landasannya adalah hadis-hadis Rasulullah shallallahu alaihi wasallam yang berisi perintah meluruskan dan merapatkan $\mathrm{saf}^{27}$ dan pendapat sebagian ulama yang menyatakan bahwa meluruskan dan merapatkan saf hukumnya wajib. ${ }^{28}$ Sedang salat dengan tata cara sebagaimana disebutkan di atas berarti melanggar perkara yang wajib.

${ }^{25}$ Salah seorang ulama senior di kota Madinah Saudi Arabia, pernah menjabat menjadi wakil rektor Universitas Islam Madinah di tahun 1393-1399 H. Beliau salah seorang pengajar resmi di Masjid Nabawi sejak tahun $1406 \mathrm{H}$ hingga sekarang, lihat: https://al-abbaad.com/profile Diakses pada 8 April 2020.

${ }^{26}$ https://twitter.com/abdul4455_com/status/1238871363290640384 Diakses pada $\underline{5 \text { April }}$ $\underline{2020 .}$.

${ }^{27} \mathrm{Di}$ antaranya sabda Nabi Muhammad shallallahu 'alaihi wasallam:

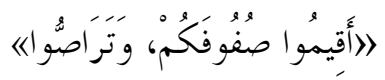

"Luruskan saf-saf kalian dan rapatkan.” (H.R. Bukhari no. 719)

${ }^{28} \mathrm{Di}$ antara ulama yang menyatakan kewajiban meluruskan dan merapatkan saf adalah Imam Bukhari, Ibnu Taimiyyah dan Ibnu Utsaimin. Lihat: https://islamqa.info/ar/answers/36881 dan https://www.alukah.net/sharia/0/90602/ ftn70 Diakses pada 5 April 2020.

Eko Misbahuddin H., Muhammad Yusram. Hukum Salat Berjemaah... 
Majelis Eropa untuk Fatwa dan Riset (The European Council for Fatwa and Research). Dalam fatwa no. 7/30 (28 Maret 2020), ${ }^{29}$ sebagai jawaban atas pertanyaan tentang salat berjemaah dengan cara social distancing, lembaga ini menjawab: "Pada kondisi seperti ini sebaiknya salat di masjid dihentikan sementara, dan dilaksanakan di rumah masing-masing. Salat berjemaah (di masjid) hukumnya sunah muakadah, sedangkan menjaga keselamatan jiwa manusia hukumnya wajib, sehingga mengutamakan perkara sunah atas perkara wajib tidak tepat. Salat dengan cara tersebut terkesan dipaksakan dan mempersulit perkara yang dimudahkan Allah, ia juga bertolak belakang dengan ruh/hikmah disyariatkannya salat berjemaah, menyalahi nas-nas yang memerintahkan untuk merapatkan saf dan melarang salat sendirian di belakang saf. Selain itu, cara seperti ini tidak menjamin orang-orang terhindar dari penularan virus, sebab mereka tetap bercampur saat masuk dan keluar, sujud di tempat yang sama, begitu pula saat membuka pintu. Masjid haruslah menjadi contoh kedisiplinan terhadap peraturan dan undang-undang, juga dalam kehatihatian dalam melindungi jiwa manusia, bukan malah sebaliknya."30

Pendapat kedua; salat tersebut sah dan tetap mendapat pahala salat berjemaah. Di antara ulama kontemporer yang berpendapat bahwa salat seperti ini sah adalah Prof. Dr. Khalid bin Ali al-Musyaiqih. ${ }^{31}$

Dalam artikel yang berjudul Hukum-hukum Fikih Terkait Virus Corona halaman 17, masalah fikih nomor 17, tentang hukum saf yang berjauhan dalam salat berjemaah, ${ }^{32}$ beliau menulis:

"Sunah (tuntunan Rasulullah) bahwa saf salat haruslah berdekatan, jarak antara satu saf dengan saf berikutnya adalah seukuran tempat sujud. Tetapi jika (berjauhan jarak) diperlukan karena khawatir terjangkit penyakit, maka berjauhan saf tidak mengapa, walaupun seorang harus salat sendiri di belakang saf karena hajat (kebutuhan). Syaikhul Islam Ibnu Taimiyyah berpendapat bahwa merapatkan saf hukumnya wajib, tetapi jika dibutuhkan

${ }^{29}$ https://www.e-cfr.org/ Diakses pada 5 April 2020.

${ }^{30}$ Penulis melihat bahwa fatwa ini tidak menyebutkan secara eksplisit hukum salat dengan cara di atas. Namun dapat dipahami bahwa hukumnya sama dengan fatwa Syekh Abdul Muhsin al-Abbad, yakni salatnya sah, namun tidak mendapat pahala salat berjemaah. Wallahu A'lam.

${ }^{31}$ Salah seorang guru besar di bidang fikih pada Qassim University KSA. Beliau memiliki banyak karya ilmiah yang sangat berharga, di antaranya: Fiqh al-I'tikaf, Ahkam al-Zakah dan Hasyiah al-Raudh al-Murbi'. Lihat: https://ar.islamway.net/scholar/330/profile Diakses pada 8 April 2020.

${ }^{32}$ https://islamhouse.com/ar/books/2829154/ Diakses pada 5 April 2020. 
(untuk salat sendiri) seperti jika saf sudah penuh, maka salatnya sah dan kewajiban sejajar dengan saf menjadi gugur. Begitu pula -wallahu 'alamjika ia takut terjangkit penyakit, kemudian salat sendirian di belakang saf, maka salatnya sah, meskipun pada asalnya berbaris di saf hukumnya wajib, berdasarkan hadis Rasulullah shallallahu 'alaihi wasallam yang diriwayatkan Ali bin Syaiban radhiyallahu 'anhu, Rasulullah bersabda:

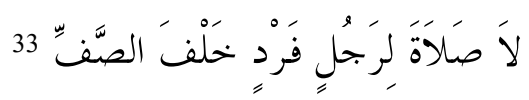

Artinya:

(Tidak (sah) salat orang yang sendirian di belakang saf)" H.R. Ahmad (no. 16297)

Pendapat kedua ini sesuai pandangan jumhur ulama mazhab Syafi'i dan Hambali, di mana ulama mazhab Syafi'i menganggap sah iqtida' (bermakmum) kepada imam, sedang jarak antara keduanya 3 dzira' (sekitar 1,5 meter), begitu juga jika jarak antara saf pertama dan kedua dan seterusnya, atau antara seorang makmum dengan makmum lain di sebelah kanan atau kirinya, meski jarak antara mereka 3 dzira' (sekitar 1,5 meter), batas maksimal jarak antara imam dan makmum, antara satu saf dengan saf yang lain, atau satu orang dengan yang lainnya disebutkan 300 dzira' (sekitar 150 meter), dengan syarat makmum dapat melihat salat imam atau mendengar suara takbirnya.

Semua dianggap sah dalam kondisi normal, apalagi jika ada uzur atau sebab tertentu yang memaksa jemaah saling mengambil jarak aman antara satu sama lain seperti saat penyebaran virus covid-19. Ini berkaitan dengan salah satu syarat berjemaah yang disebutkan dalam mazhab Syafi'i, yakni berkumpulnya imam dan makmum di satu masjid (tempat). Meski demikian, semua ulama sepakat bahwa salat berjemaah dengan saf yang lurus dan rapat tentu lebih afdal.

Imam al-Rafi'i berkata:

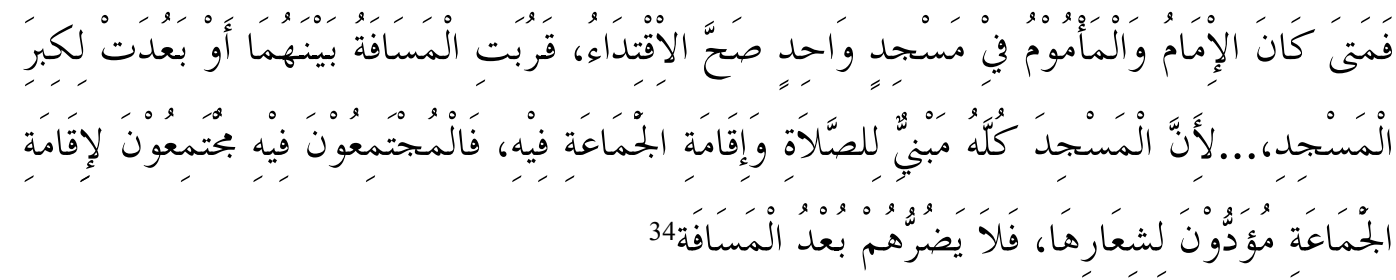

${ }^{33}$ Ahmad bin Muhammad bin Hambal, Musnad al-Imam Ahmad bin Hambal, (Cet. I; Beirut: Muassasah al-Risalah, $1421 \mathrm{H} / 2001 \mathrm{M}$ ).

${ }^{34}$ Abdul Karim bin Muhammad bin Abdul Karim al-Rafi'i, Al-Aziz Syarh al-Wajiz, Jilid II (Cet. I; Beirut: Dar al-Kutub al-Ilmiyah, 1417 H/ 1997 M) h. 177. 
Artinya:

'Kapan saja imam dan makmum berada di satu masjid, maka iqtida' (berimam kepadanya) sah, baik jarak antara keduanya berdekatan atau berjauhan dikarenakan luasnya masjid, sebab masjid didirikan untuk salat dan berjemaah di dalamnya, semua yang berkumpul di dalamnya berkumpul untuk menegakkan jemaah, maka jarak yang berjauhan tidak mempengaruhinya."

Imam Nawawi menambahkan syarat sahnya jemaah tersebut meski berjauhan jaraknya:

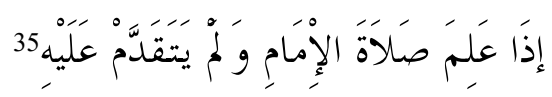

Artinya:

"Jika ia (makmum) mengetahui salat imam, dan tidak berdiri di depannya."

Lebih rinci lagi, Imam Nawawi menyebutkan:

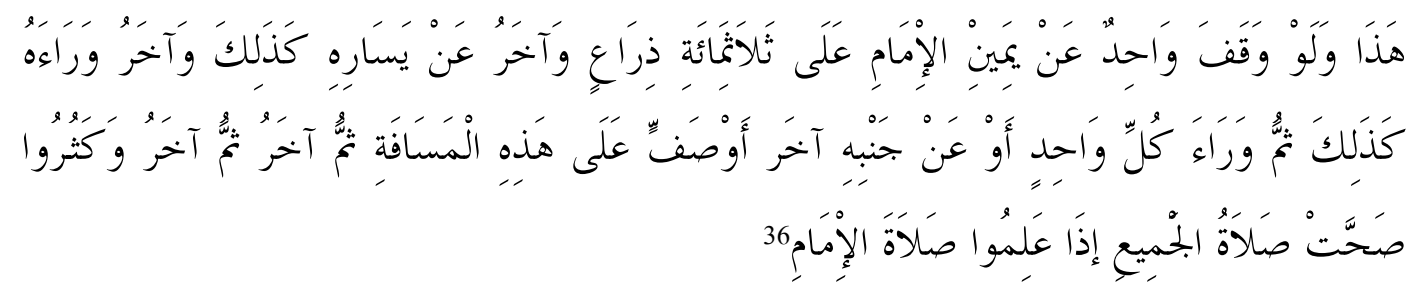

Artinya:

"Dengan demikian, jika seorang (makmum) berdiri di sebelah kanan imam sejauh 300 dzira' (sekitar 150 meter), makmum lain di sebelah kirinya dengan jarak yang sama, makmum lain di belakangnya dengan jarak seperti itu, kemudian di belakang atau di samping setiap makmum tersebut ada satu orang atau satu saf dengan jarak yang sama, kemudian disambung oleh yang lain, demikian seterusnya, salat mereka semua sah, jika mereka mengetahui salat imam."

${ }^{35}$ Muhyiddin Yahya bin Syaraf al-Nawawi, Al-Majmu' Syarh al-Muhadzdzab, Jilid IV (t.t.: Dar al-Fikr, t.th.), h. 303.

${ }^{36}$ Muhyiddin Yahya bin Syaraf al-Nawawi, Al-Majmu' Syarh al-Muhadzdzab, Jilid IV (t.t.: Dar al-Fikr, t.th.), h. 305. 
Imam Ibnu Qudamah al-Maqdisi al-Hambali berkata:

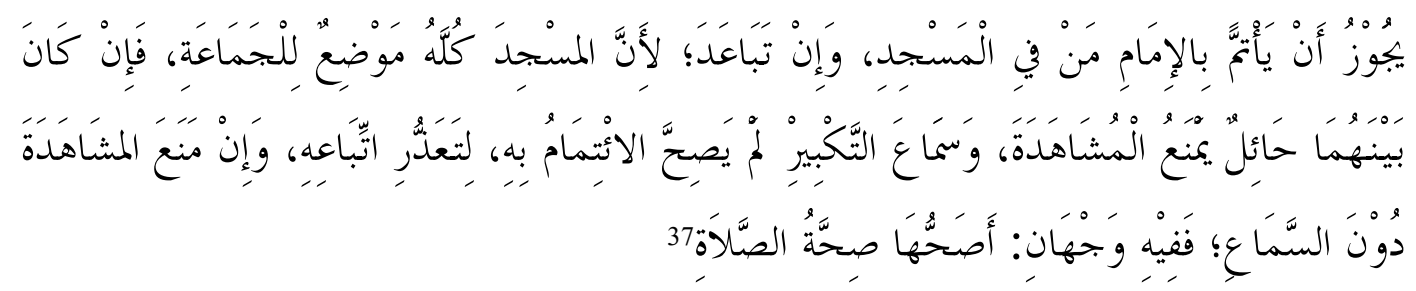

Artinya:

"Siapa saja yang berada di masjid boleh mengikuti (salat) imam, meski jarak keduanya berjauhan, sebab keseluruhan masjid adalah tempat untuk berjemaah, jika di antara keduanya ada penghalang sehingga imam tidak terlihat, dan ia tidak bisa mendengar takbir imam, maka tidak sah berimam dengannya, tetapi jika tidak melihat imam namun mendengar takbirnya maka ada dua pendapat (dalam mazhab), yang paling benar bahwa salatnya sah."

Adapun pendapat pertama, yang menyatakan bahwa meluruskan dan merapatkan saf dalam salat berjemaah hukumnya wajib, tetapi jika ada uzur yang menyebabkan seseorang tidak rapat dengan saf, maka sejatinya salat jemaahnya tetap sah.

Ibnu Hajar al-Asqalani berkata:

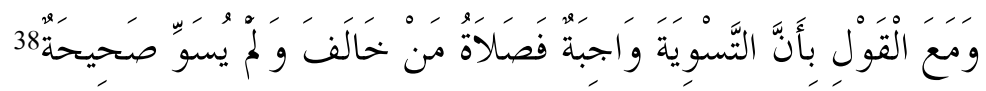

Artinya:

"Sesuai pendapat yang menyatakan meluruskan saf hukumnya wajib, akan tetapi salat orang yang tidak meluruskan saf tetaplah sah."

Ibnu Taimiyyah juga berkata:

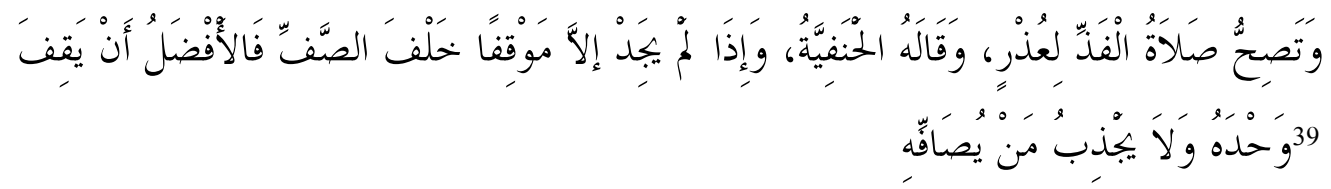

Artinya:

${ }^{37}$ Abdullah bin Ahmad Ibnu Qudamah al-Maqdisi, Al-Kafi fi Fiqh al-Imam Ahmad, Jilid I (Cet. I; Beirut: Dar al-Kutub al-Ilmiyah, 1414 H/ 1994 M), h. 302.

${ }^{38}$ Ahmad bin Ali Ibnu Hajar al-Asqalani, Fath al-Bari, Jilid II (Beirut: Dar al-Ma'rifah, 1379 H), h. 210.

${ }^{39}$ Ahmad bin Abdul Halim bin Abdul Salam Ibnu Taimiyyah, Al-Fatawa al-Kubra, Jilid V (Cet. I; t.t.: Dar al-Kutub al-Ilmiyah, 1408 H/ 1987 M) h. 348. 
"Dan salat orang yang sendirian (di belakang saf) karena sebuah uzur hukumnya sah, sama dengan pendapat mazhab Hanafi, dan jika ia tidak mendapat tempat selain di belakang saf, maka lebih afdal ia salat sendirian, dan tidak menarik orang yang di depannya."

Pendapat ini menjadi lebih kuat karena jumhur ulama berpendapat bahwa merapatkan dan meluruskan saf hukumnya sunah/mustahab, bukan wajib.

\section{KESIMPULAN}

Jika arahan untuk menghentikan sementara salat Jumat dan salat berjemaah di masjid masih sekadar imbauan, kemudian sebuah lembaga atau badan takmir masjid memilih tetap melaksanakan salat berjemaah di masjid dengan menerapkan cara social distancing, maka salat jemaah mereka insyaallah- tetap sah, sebagaimana pendapat kedua tersebut di atas.

Akan tetapi, menaati imbauan pihak berwenang baik pemerintah atau MUI lebih dianjurkan dan diutamakan. Oleh karena imbauan tersebut meski belum diwajibkan, sepenuhnya demi kemaslahatan masyarakat secara umum, dan imbauan dikeluarkan lantaran mempertimbangkan bahaya wabah covid-19 yang sudah jelas dan nyata adanya. Keluarnya imbauan tersebut sudah cukup untuk dijadikan sebagai uzur dalam meninggalkan salat berjemaah di masjid dan mengganti salat Jumat dengan salat Zuhur empat rakaat. Apalagi jemaah yang tetap memilih salat berjemaah di masjid ada yang disemprot disinfektan, mengenakan masker, dan menerapkan social distancing, semuanya dilakukan demi menjaga dan khawatir (takut) tertular virus covid-19, dan rasa takut ini juga menjadi uzur tambahan untuk salat berjemaah di rumah.

\section{DAFTAR PUSTAKA}

Al-Qur'an.

Ahmad bin Muhammad bin Hambal. (1421 H/ 2001 M). Musnad al-Imam Ahmad bin Hambal. Cet. I. Beirut: Muassasah al-Risalah.

Al-Asqalani, Ahmad bin Ali Ibnu Hajar. (1379). Fath al-Bari. Jilid II Beirut: Dar al-Ma'rifah.

Al-Abbad Abdul Muhsin. "Profil Abdul Muhsin al-Abbad." https://alabbaad.com/profile, (Diakses pada tanggal 8 April 2020). . "Hukum Salat Berjemaah dengan Cara Sosial Distancing." https://twitter.com/abdul4455 com/status/1238871363290640384,

(Diakses pada tanggal 5 April 2020). 
Al-Maqdisi, Abdullah bin Ahmad Ibnu Qudamah. (1414 H/ 1994 M). Al-Kafi fi Fiqh al-Imam Ahmad. Jilid I. Cet. I. Beirut: Dar al-Kutub al-Ilmiyah. al-Munajjid Sholeh. "Di antara ulama yang menyatakan kewajiban meluruskan dan merapatkan saf adalah Imam Bukhari, Ibnu Taimiyyah dan Ibnu Utsaimin" https://islamqa.info/ar/answers/36881, (Diakses pada tanggal 5 April 2020).

Al-Musyaiqih Khalid bin Ali. "Profil Prof. Dr. Khalid bin Ali al-Musyaiqih" https://ar.islamway.net/scholar/330/profile, (Diakses pada tanggal 8 April 2020).

. "Artikel Berjudul Hukum-hukum Fikih Terkait Virus Corona Halaman 17, Masalah Fikih Nomor 17’ https://islamhouse.com/ar/books/2829154/, (Diakses pada tanggal 5 April 2020).

Al-Nawawi, Muhyiddin Yahya bin Syaraf. Al-Majmu' Syarh al-Muhadzdzab. Jilid IV. Dar al-Fikr.

Al-Osail, Aisha M. and Marwan J. Al-Wazzah. (2017). The History and Epidemiology of Middle East Respiratory Syndrome Corona Virus. Multidisciplinary Respiratory Medicine 12:20. DOI 10.1186/s40248-0170101-8.

Al-Rafi'i, Abdul Karim bin Muhammad bin Abdul Karim. (1417 H/ 1997 M). AlAziz Syarh al-Wajiz. Jilid II. Cet. I. Beirut: Dar al-Kutub al-Ilmiyah.

Al-Subki, Tajuddin Abdul Wahhab bin Taqiyuddin. (1411 H/ 1991 M). AlAsybah wa al-Nazhair. Jilid I. Cet. I. Beirut: Dar al-Kutub al-Ilmiyah.

Al-Syaukani, Muhammad bin Ali bin Muhammad. (1419 H/ 1999 M). Irsyadul Fuhul ila Tahqiq al-Haq min 'Ilmi al-Ushul. Jilid II. Cet. I. Damaskus: Dar al-Kitab al-Arabi.

Al-Zarkasyi, Muhammad bin Abdullah bin Bahadir. (1413 H/ 1992 M). Al-Bahru al-Muhith fi Ushul al-Fiqh, Wizarah al-Awqaf wa al-Syuun al-Islamiyah. Jilid VI. Cet. II. Kuwait: t.p.

Buana, Dana Riksa. (2020). Analisis Perilaku Masyarakat Indonesia dalam Menghadapi Pandemi Virus Corona (Covid-19) dan Kiat Menjaga Kesejahteraan Jiwa. Salam: Jurnal Sosial dan Budaya Syar'i, Vol 7, No. 3. h. 217-226.

detiknews. "Tentang Social Distance, Cara Pemerintah Cegah Penyebaran Virus Corona." $\quad$ https://news.detik.com/berita/d-4940726/tentang-socialdistance-cara-pemerintah-cegah-penyebaran-virus-corona, (Diakses pada tanggal 7 April 2020).

. "Kemenkes: Rapid Test Massal Corona akan Dikonfirmasi Tes PCR." https://news.detik.com/berita/d-4945831/kemenkes-rapid-test-massalcorona-akan-dikonfirmasi-tes-per (Diakses pada tanggal 4 April 2020). 
El-hmaid Saad bin Abdallah \& El-Jeraissy Khaled bin Abdulrahman. "Di antara ulama yang menyatakan kewajiban meluruskan dan merapatkan saf adalah Imam Bukhari, Ibnu Taimiyyah dan Ibnu Utsaimin." https://www.alukah.net/sharia/0/90602/ ftn70, (Diakses pada tanggal 5 April 2020).

Gugus Tugas Percepatan Penanganan Covid-19. "Sebanyak 164 Orang Sembuh dan 2.273 Positif COVID-19 di Indonesia." https://www.covid19.go.id/, (Diakses pada tanggal 5 April 2020).

Haerul, Akib dan Hamdan. (2016). Implementasi Kebijakan Program Makassar Tidak Rantasa di Kota Makassar. Jurnal Administrasi Publik, Volume 6, No. 2.

Ibnu Katsir, Ismail bin Umar bin Katsir al-Dimasyqi. (1420 H/ 1999 M). Tafsir al-Qur'an al-Azhim. Jilid II. Cet. II. Riyadh: Dar al-Thayyibah.

Ibnu Taimiyyah, Ahmad bin Abdul Halim bin Abdul Salam. (1408 H/ 1987 M). Al-Fatawa al-Kubra. Jilid V. Cet. I. t.t.: Dar al-Kutub al-Ilmiyah.

Indriya. (2020). Konsep Tafakkur dalam Alquran dalam Menyikapi Coronavirus Covid-19. Salam: Jurnal Sosial dan Budaya Syar'I, Vol 7, No. 3. h. 211216.

Iskandar, A., Aqbar, K. (2019). Kedudukan Ilmu Ekonomi Islam di Antara Ilmu Ekonomi dan Fikih Muamalah: Analisis Problematika Epistemologis. NUKHBATUL 'ULUM: Jurnal Bidang Kajian Islam, Vol. 5. No. 2. h. 88-105.

Kementerian Kesehatan. "Dokumen Resmi dan Protokol Penanganan Covid-19." https://www.kemkes.go.id/article/view/20031700001/Dokumen-Resmidan-Protokol-Penanganan-COVID-19.html, (Diakses pada tanggal 7 April 2020).

Lau, Hien, et.all. The Positive Impact of Lockdown in Wuhan on Containing the COVID-19 Outbreak in China. Journal of Travel Medicine. taaa037. https://doi.org/10.1093/jtm/taaa037.

Majelis Ulama Indonesia. "Fatwa Penyelenggaraan Ibadah dalam Situasi Terjadi Wabah Covid-19" https://mui.or.id/berita/27674/fatwa-penyelenggaraanibadah-dalam-situasi-terjadi-wabah-covid-19/, (Diakses pada tanggal 7 April 2020)

Mukharom dan Havis Aravik. (2020). Kebijakan Nabi Muhammad Saw. Menangani Wabah Penyakit Menular dan Implementasinya dalam Konteks Menanggulangi Coronavirus Covid-19. Salam: Jurnal Sosial dan Budaya Syar'i, Vol. 7. No. 3. h. 239-246.

Santoso. B., \& Pramudita. Y. A ."Pemerintah Tekankan Social Distancing Harus Sampai 
social-distancing-harus-sampai-lingkup-keluarga, (Diakses pada tanggal 7 April 2020).

Syandri dan Fadlan Akbar. (2020). Penggunaan Masker Penutup Wajah Saat Salat sebagai Langkah Pencegahan Wabah Coronavirus Covid-19. Salam: Jurnal Sosial dan Budaya Syar'i. Vol. 7. No. 3, h. 261-268.

The European Council for Fatwa and Research. "Fatwa no. 7/30." https://www.ecfr.org/, (Diakses pada tanggal 5 April 2020)

Whitworth, Jimmy. (2020). COVID-19: A Fast Evolving Pandemic, Trans R Soc Trop Med Hyg 2020; 00: 1-2. doi:10.1093/trstmh/traa025.

Yunus, Nur Rohim dan Annissa Rezki. (2020). Kebijakan Pemberlakuan Lockdown sebagai Antisipasi Penyebaran Corona Virus Covid-19. Salam: Jurnal Sosial dan Budaya Syar'I, Vol. 7. No. 3, h. 227-238.

Zahrotunnimah. (2020). Langkah Taktis Pemerintah Daerah dalam Pencegahan Penyebaran Virus Corona Covid-19 di Indonesia. Salam: Jurnal Sosial dan Budaya Syar'i. Vol. 7. No. 3, h. 247-260. 